\title{
ANALISIS TINGKAT KETAHANAN PANGAN RUMAH TANGGA PETANI SAWAH IRIGASI DI DESA CENDI MANIK KECAMATAN SEKOTONG KABUPATEN LOMBOK BARAT
}

\section{ANALYSIS OF HOUSEHOLD FOOD SECURITY LEVEL OF IRRIGATED RICE FARMERS IN CENDI MANIK VILLAGE IN SEKOTONG SUB-DISTRICT OF WEST LOMBOK DISTRICT}

\author{
Sumarni, Candra Ayu, dan Tajidan \\ Program Studi Agribisnis Fakultas Pertanian Universita Mataram
}

\begin{abstract}
ABSTRAK
Kecamatan Sekotong merupakan daerah terluas di Kabupaten Lombok Barat. Berdasarkan data Badan Pusat Statistik (BPS) Kabupaten Lombok Barat bahwa produksi padi Kecamatan Sekotong berada pada urutan ke-6 terbanyak. Guna meningkatkan produksi pertanian di wilayah ini, pemerintah membangun beberapa irigasi (embung). Penelitian dilakukan di Desa Cendi Manik Kecamatan Sekotong dengan metode purposive sampling. Pengumpulan data dilakukan melalui wawancara dan dari dinas terkait. Hasil penelitian menunjukkan bahwa ratarata total pendapatan rumahtangga petani sawah irigasi sebesar Rp 17.734.644/tahun, sedangkan rata-rata pengeluaran rumah tangga petani sawah irigasi sebesar Rp 14.208.012/ tahun; kondisi ketahanan pangan rumah tangga petani sawah irigasi tergolong rawan pangan sebanyak 15 responden (75\%), kurang pangan sebanyak 2 responden (10\%), rentan pangan sebanyak 3 responden (15\%), dan tidak ada responden yang tergolong tahan pangan; masalah yang dirasakan oleh petani sawah irigasi dalam mewujudkan ketahanan pangan rumah tangga yaitu pada aspek lingkungan fisik saja berupa ketersediaan air sebanyak 9 responden (45\%), kesuburan tanah (40\%), dan hama penyakit sebanyak 3 orang (15\%). Disarankan kepada pemerintah, memberikan sosialisasi dan bimbingan secara berkelanjutan mengenai pentingnya mewujudkan ketahanan pangan rumah tangga dengan mengkonsumsi makanan yang mengandung kalori dan protein cukup.
\end{abstract}

Kata Kunci: Kecukupan Energi, Pangsa Pengeluaran Pangan, Ketahanan Pangan 


\begin{abstract}
Sekotong District is the largest area in West Lombok Regency. Rice production in Sekotong District ranks the 6th most. In order to increase agricultural production in this region, the government built some irrigation (embung). The study was conducted in Cendi Manik Village, Sekotong District with the purposive sampling method. Data collection was carried out through interviews and from related agencies. The results showed that the average total household income of irrigated rice farmers was Rp 17,734,644.11/year, while the average expenditure of irrigated rice farmers was Rp 14,208,012/year; the food security conditions of irrigated rice farmers households are classified as food insecurity as many as 15 respondents (75\%), lack of food as much as 2 respondents (10\%), food insecurity as much as 3 respondents (15\%), and no respondents are classified as food resistant; the problem felt by irrigated rice farmers in realizing household food security is in the physical environment aspect in the form of water availability as many as 9 respondents (45\%), soil fertility (40\%), and disease pests as many as 3 people (15\%). It is recommended to the government providing ongoing socialization and guidance on the importance of realizing household food security by consuming foods that contain enough calories and protein.
\end{abstract}

\title{
Keywords: Energy Adequacy, Food Expenditures Share, Food Security
}

\section{PENDAHULUAN}

Pemenuhan kebutuhan pangan bertujuan untuk membangun sumberdaya manusia berkualitas, yang diharapkan menjadi penggerak perubahan bangsa, namun faktanya tidak semua orang mampu memenuhi kebutuhan pangan tersebut. Kecamatan Sekotong merupakan daerah terluas di Kabupaten Lombok Barat, tepatnya 50,23\% wilayah Kabupaten Lombok Barat berada di Kecamatan Sekotong. Akan tetapi, produksi pertanian yang dihasilkan Kecamatan Sekotong tidak berbanding lurus dengan luas wilayahnya. Berdasarkan data Badan Pusat Statistik (BPS) Kabupaten Lombok Barat guna meningkatkan produksi pertanian, terutama produksi padi sebagai bahan pangan pokok penduduk maka pemerintah membangun beberapa irigasi (embung). Menurut BPS Kecamatan Sekotong dalam Angka 2018, Desa Cendi Manik memiliki sawah terluas, yakni 485 ha. Namun total produksi padi berada pada urutan ke-3 setelah Desa Sekotong Barat dan Desa Pelangan. Hal ini mempengaruhi kualitas dan tingkat ketahanan pangan keluarga petani di Desa Cendi Menik. Selain itu, tingkat ketahanan pangan rumah tangga dipengaruhi oleh berbagai hal seperti pendapatan rumah tangga, kesadaran individu akan kualitas pangan yang dikonsumsi, dan hambatan yang dihadapi rumah tangga dalam mewujudkan ketahanan pangan.

Penelitian ini bertujuan untuk menganalisis pendapatan dan pengeluaran, tingkat ketahanan pangan, serta mengkaji masalah/hambatan yang dihadapi rumahtangga petani sawah irigasi dalam mewujudkan ketahanan pangan di Desa Cendi Manik Kecamatan Sekotong Kabupaten Lombok Barat. Hasil penelitian ini diharapkan bermanfaat bagi pemerintah sebagai dasar pengambilan keputusan pembangunan pertanian khususnya di lokasi penelitian. 


\section{METODE PENELITIAN}

Penelitian ini dilakukan di Desa Cendi Manik Kecamatan Sekotong Kabupaten Lombok Barat dengan pertimbangan bahwa desa ini merupakan daerah dengan sawah irigasi terluas dan memiliki beberapa embung sebagai irigasi. Penelitian ini menggunakan metode deskriptif, yaitu penyelesaian masalah dengan memberikan gambaran secara sistematis, faktual, dan akurat mengenai populasi maupun lingkungan populasi.

Penentuan jumlah responden dilakukan dengan metode quota sampling yakni sebanyak 20 orang. Penentuan petani responden dilakukan dengan metode accidental sampling. Data yang terkumpul dianalisis dengan cara berikut :

a. Ketahanan Pangan Rumah Tangga Petani ditentukan menggunakan klasifikasi silang dua indikator ketahanan pangan (proporsi pengeluaran pangan dan tingkat konsumsi energi), maka pengukuran derajat ketahanan pangan rumah tangga dikelompokkan menjadi empat kategori yaitu:

- Tahan pangan bila proporsi pengeluaran pangan rendah $(<60 \%$ dari pengeluaran total rumah tangga) dan cukup mengkonsumsi energi (>80\% dari syarat kecukupan gizi)

- Kurang pangan bila proporsi pengeluaran pangan rendah ( $<60 \%$ dari pengeluaran total rumah tangga) dan kurang mengkonsumsi energi ( $\leq 80 \%$ dari syarat kecukupan gizi)

- Rentan pangan bila pangsa pengeluaran pangan tinggi ( $\geq 60 \%$ dari pengeluaran total rumah tangga) dan cukup mengkonsumsi energi (>80\% dari syarat kecukupan gizi)

- Rawan pangan bila proporsi pengeluaran pangan tinggi ( $\geq 60 \%$ dari pengeluaran total rumah tangga) dan kurang mengkonsumsi energi ( $\leq 80 \%$ dari syarat kecukupan gizi

Standar angka ketetapan energi adalah sebesar $2.150 \mathrm{kkal} / \mathrm{kapita} / \mathrm{hari}$ dan angka ketetapan protein adalah $57 \mathrm{gr} / \mathrm{kapita/hari} \mathrm{(Hardiansyah,} \mathrm{et} \mathrm{al.,} \mathrm{2013).}$

b. Proporsi pengeluaran pangan terhadap total pengeluaran rumah tangga petani dengan rumus (Azizah, Putritamara, dan Febrianto, 2019):

$$
\mathrm{PF}=\frac{P P}{T P} \boldsymbol{x} 100 \%
$$

Keterangan :

PF : Proporsi pengeluaran pangan (\%)

PP : Pengeluaran pangan (Rupiah)

TP : Total pengeluaran (Rupiah)

Untuk mengukur jumlah konsumsi energi dengan rumus:

$$
\mathrm{Gej}=\frac{B P j}{100} x \frac{B d d j}{100} x K G e j
$$

c. Konsumsi protein dihitung dengan rumus sebagai berikut:

$$
\mathrm{Gpj}=\frac{B P j}{100} x \frac{B d d j}{100} x K G p j
$$

Keterangan:

Gej : Energi yang dikonsumsi dari pangan j (kkal/kap/hari)

Gpj : Protein yang dikonsumsi dari pangan j (gram/kap/hari)

$\mathrm{BPj}$ : Berat makanan j yang dikonsumsi (gram/kap/hari) 
Bddj : Bagian yang dapat dimakan (dalam persen atau gram dari 100 gram pangan j)

Kgij : Kandungan zat gizi tertentu (i) dari 100 gram pangan j atau makanan yang dikonsumsi

d. Pendapatan dan Pengeluaran Rumah Tangga Petani dihitung dengan rumus (Azizah, Putritamara, dan Febrianto, 2019):

$$
\mathbf{P d}_{\mathrm{d}}=\mathbf{P d}_{\text {on }}+\mathbf{P d}_{\text {off }}
$$

Keterangan:

$\mathrm{Pd} \quad$ : pendapatan rumah tangga petani (Rupiah)

$\mathrm{Pd}_{\text {on }}$ : pendapatan dari usahatani (Rupiah)

$\mathrm{Pd}_{\text {off }}$ : pendapatan dari luar usahatani (Rupiah)

e. Total pengeluaran rumah tangga diketahui dengan menjumlahkan pengeluaran pangan dan nonpanan rumah tangga petani.

f. Ketersediaan Pangan Pokok (Beras) diukur dengan rumus (Adiguna dkk dalam Rahayu, 2014):

$$
\text { S = Input }- \text { output }
$$

Keterangan :

S : Ketersediaan pangan pokok (beras) rumah tangga petani

Input : Pangan pokok dari produksi usahatani, pembelian, atau pemberian (gram/ kap/ hari) dikonversi ke (kkal/kap/hari)

Output : Pangan pokok yang dijual, kegiatan sosial, diberikan kepada pihak lain (gram/kap/hari) dikonversi ke (kkal/kap/hari)

Kriteria ketersediaan energi dari pangan pokok (beras) adalah:

- Tinggi : Ketersediaan energi $\geq 1.600 \mathrm{kkal} / \mathrm{kapita} / \mathrm{hari}$

- Sedang : Ketersediaan energi antara 1.400-1.599 kkal/kapita/hari

- Rendah : Ketersediaan energi <1.400 kkal/kapita/hari.

g. Akses Pangan Rumah Tangga Petani sebagai berikut:

- $1,00-<2,00$ akses pangan sangat rendah

- $2,00-<3,00$ akses pangan rendah

- 3,00 - <4,00 akses pangan cukup rendah

- $4,00-<5,00$ akses pangan cukup tinggi

- $5,00-<6,00$ akses pangan tinggi

- $\quad \geq 6,00$ akses pangan sangat tinggi

h. Konsumsi Pangan Rumah Tangga Petani dilihat dari kualitas dan kuantitas pangan. Kualitas pangan mencerminkan zat gizi yang dibutuhkan oleh tubuh yang terdapat dalam bahan pangan, sedangkan Kuantitas pangan mencerminkan jumlah setiap gizi dalam suatu bahan pangan.Untuk menilai konsumsi pangan secara kuantitatif digunakan parameter Tingkat Konsumsi Energi (TKE) dan Tingkat Konsumsi Protein (TKP).

$$
\text { TKE }=\frac{\text { Ekonsumsienergi }}{\text { AKEyangdianjurkan }} x 100 \%
$$




$$
\mathrm{TKP}=\frac{\text { Ekonsumsiprotein }}{\text { AKPyangdianjurkan }} x 100 \%
$$

\section{Keterangan:}

TKE

: Tingkat konsumsi energi (\%)

TKP : Tingkat konsumsi protein (\%)

$\sum$ konsumsi energi : jumlah konsumsi energi (kkal/kapita/hari)

$\sum$ konsumsi protein : jumlah konsumsi protein (gram/kapita/hari)

Perbandingan antara konsumsi zat gizi dengan angka kecukupan gizi yang dianjurkan disebut sebagai tingkat konsumsi gizi (TKG). TKG diklasifikasikan pada nilai kecukupan gizi yang dikonsumsi berdasarkan acuan Depkes (2000) dalam Supariasa (2002), yakni:
a. Baik $\quad:$ TKG $\geq 100 \%$ AKG
b. Sedang : TKG $80-99 \%$ AKG
c. Kurang : TKG $70-80 \%$ AKG
d. Defisit $\quad:$ TKG $<70 \%$ AKG

\section{HASIL DAN PEMBAHASAN}

\section{Pendapatan Rumah Tangga Petani}

Pendapatan rumah tangga petani sebesar Rp 17.734.644,11/tahun yang diperoleh dari kegiatan pertanian sebesar Rp 7.837.944,11/tahun (44,20\%) dan dari kegiatan non pertanian sebesar Rp 9.896.700/tahun (55,80\%). Pendapatan dari kegiatan non pertanian lebih besar dibandingkan dari kegiatan pertanian. Hal ini yang menyebabkan petani tidak hanya fokus pada kegiatan pertanian saja tetapi juga melakukan kegiatan di luar usahatani. Rincian pendapatan rumahtangga petani sawah irigasi di Desa Cendi Menik Kecamatan Sekotong pada tahun 2019 selengkapnya pada Tabel 1.

Tabel 1. Pendapatan Petani Sawah Irigasi di Desa Cendi Manik Kecamatan Sekotong Tahun 2019

\begin{tabular}{|c|c|c|c|}
\hline No. & $\begin{array}{c}\text { Jenis Kegiatan } \\
\text { Ekonomi Produktif }\end{array}$ & $\begin{array}{c}\text { Nilai } \\
\text { (Rp/tahun) }\end{array}$ & $\begin{array}{l}\text { Persentase } \\
\quad(\%)\end{array}$ \\
\hline 1. & $\begin{array}{l}\text { Kegiatan Pertanian } \\
\text { UT Tanaman Pangan } \\
\text { Hasil Kebun } \\
\text { Beternak (sapi) }\end{array}$ & $\begin{array}{r}5.379 .611,11 \\
85.000 \\
2.373 .333 \\
\end{array}$ & $\begin{array}{r}30,33 \\
0,48 \\
13,38 \\
\end{array}$ \\
\hline & Jumlah (1) & $7.837 .944,11$ & 44,20 \\
\hline 2. & $\begin{array}{l}\text { Kegiatan Non pertanian } \\
\text { a. Buruh Bangunan } \\
\text { b. Tukang Kayu } \\
\text { c. Sopir } \\
\text { d. Pedagang }\end{array}$ & $\begin{array}{r}1.033 .500 \\
612.000 \\
3.474 .000 \\
4.662 .000\end{array}$ & $\begin{array}{r}5,83 \\
3,45 \\
19,59 \\
26,29\end{array}$ \\
\hline
\end{tabular}




\begin{tabular}{|c|r|r|}
\hline e. Guru & 115.200 & 0,65 \\
\hline Jumlah (2) & 9.896 .700 & 55,80 \\
\hline Total Pendapatan RT Petani & $17.734 .644,11$ & 100,00 \\
\hline
\end{tabular}

Sumber: Data Primer Diolah 2019

\section{Pengeluaran Rumah Tangga Petani}

Rata-rata Pengeluaran rumah tangga petani sawah irigasi untuk pangan yang paling besar adalah untuk pangan pokok yaitu sebesar Rp 360.500 atau 44,34\% dari total pengeluaran pangan sedangkan pengeluaran pangan terkecil adalah untuk gula yakni sebesar Rp 18.900 atau 2,38\% dari total pengeluaran pangan. Hal ini dikarenakan pangan pokok (beras) merupakan makanan pokok petani sawah irigasi di Desa Cendi Manik Kecamatan Sekotong. Rincian pengeluaran rumah tangga petani sawah irigasi dapat dilihat pada Tabel 2.

Tabel 2. Pengeluaran Pangan Rumah Tangga Petani di Desa Cendi Manik Kecamatan Sekotong Tahun 2019

\begin{tabular}{|c|l|r|r|}
\hline No & \multicolumn{1}{|c|}{ Jenis Konsumsi Pangan } & $\begin{array}{r}\text { Rata-rata/bulan } \\
(\mathrm{Rp})\end{array}$ & $\begin{array}{r}\text { Persentase } \\
(\%)\end{array}$ \\
\hline 1. & Pangan Pokok: & 352.500 & 44,34 \\
& a. Beras & 5.000 & 0,63 \\
& b. Ubi Kayu & 3.000 & 0,38 \\
\hline & C. Ubi Jalar & 360.500 & 45,35 \\
\hline 2. & Jumlah (1) & & \\
& Lauk & & \\
& a. Lauk Hewani: & 14.000 & 1,76 \\
& -Daging sapi & 24.800 & 3,12 \\
& -lkan asin & 56.600 & 7,12 \\
& -lkan segar & 37.200 & 4,68 \\
\hline & -Telur & 132.600 & 16,68 \\
\hline & \multicolumn{1}{|c|}{ Jumlah (2a) } & 17.665 & 2,22 \\
& b. Lauk Nabati : & 13.875 & 1,75 \\
\hline & -Tahu & 31.540 & 3,97 \\
\hline & -Tempe & 30.000 & 3,77 \\
\hline 3. & Sayuran & 49.800 & 6,26 \\
4. & Minyak Goreng & 18.900 & 2,38 \\
5. & Gula & 30.200 & 3,80 \\
6. & Buah-buahan & 19.698 & 2,48 \\
7. & Minuman & 121.775 & 15,32 \\
\hline 8. & Bumbu-bumbuan & 795.013 & 100,00 \\
\hline & Jumlah Konsumsi Pangan & & \\
\hline
\end{tabular}


Besarnya pengeluaran rumah tangga petani sawah irigasi untuk non pangan yang paling besar adalah untuk membeli bensin yakni Rp 84.600 per bulan atau $21,75 \%$ dari total pengeluaran non pangan sedangkan pengeluaran non pangan terkecil adalah untuk membeli pakaian yakni Rp 23.063 per bulan atau $5,93 \%$ dari total pengeluaran non pangan. Pengeluaran non pangan untuk bensin menjadi pengeluaran paling besar dikarenakan kebutuhan petani menggunakan kendaraan sepeda motor cukup tinggi, baik untuk keperluan usahatani maupun non usahatani, sedangkan pengeluaran non pangan terkecil berupa pakaian dikarenakan pembelian pakaian hanya dilakukan pada waktu-waktu tertentu saja seperti pada perayaan hari raya saja. Rincian pengeluaran non pangan rumah tangga petani sawah irigasi dapat dilihat pada Tabel 3.

Tabel 3. Jumlah Pengeluaran Nonpangan Bulanan Petani Sawah Irigasi di Desa Cendi Manik Kecamatan Sekotong Tahun 2019

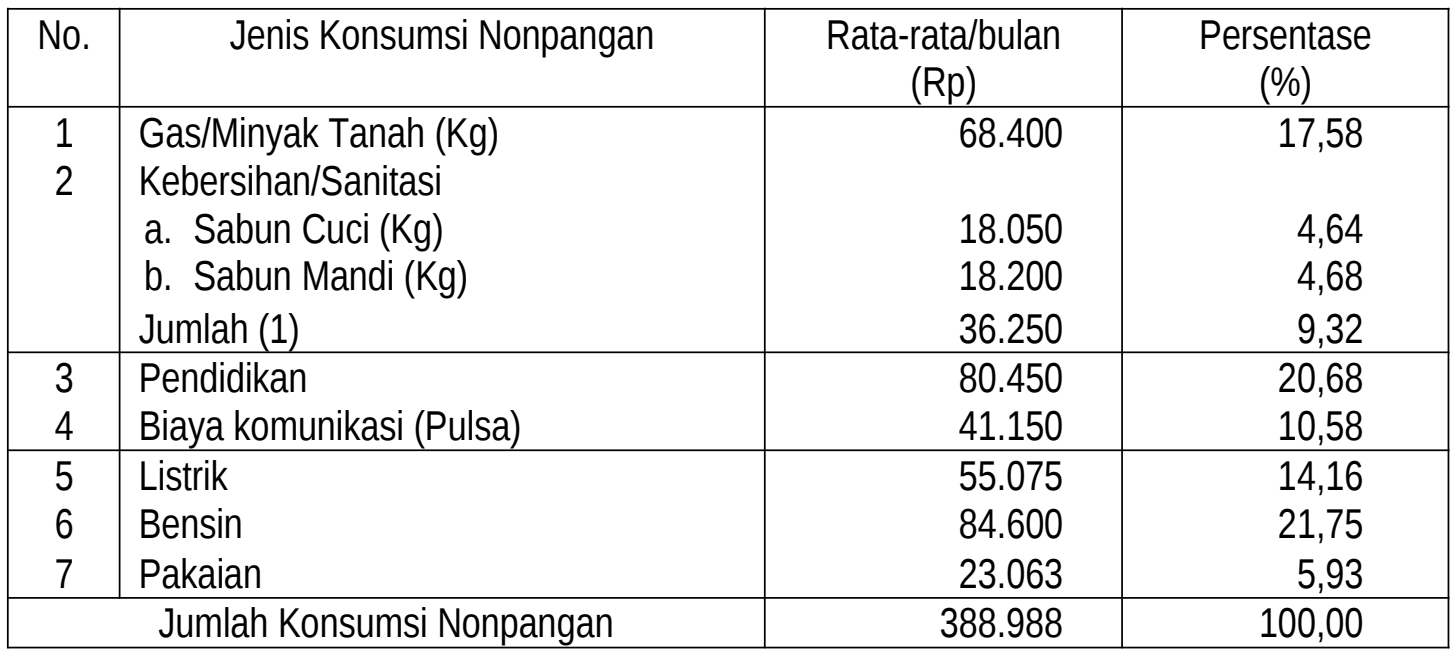

Sumber: Data Primer Diolah 2019

\section{Proporsi Pengeluaran Pangan Terhadap Total Pengeluaran}

Jumlah pengeluaran pangan rumah tangga petani sawah irigasi di Desa Cendi Manik lebih besar dari pada pengeluaran non pangan. Pengeluaran pangan dan non pangan rumah tangga petani masing-masing sebesar Rp 795.013/bulan atau 67,15\% dan Rp 388.988/bulan atau $32,85 \%$ dari total pengeluaran. Dengan demikian maka rata-rata total pengeluaran rumah tangga petani per bulan sebesar Rp 1.184.001/bulan. Rincian tentang jumlah pengeluaran rumah tangga petani sawah irigasi di Desa Cendi Manik Kecamatan Sekotong Tahun 2019 selengkapnya pada Tabel 4.

Tabel 4. Proporsi Pengeluaran Pangan Terhadap Total Pengeluaran pada Rumahtangga Petani Sawah irigasi di Desa Cendi Menik Tahun 2019

\begin{tabular}{|c|l|c|c|}
\hline No & Jenis Pengeluaran & Total Pengeluaran per Bulan (Rp) & Persentase (\%) \\
\hline 1 & Pangan & 795.013 & 67,15 \\
2 & Non Pangan & 388.988 & 32,85 \\
\hline \multicolumn{2}{|c|}{ Jumlah } & 1.184 .001 & 100,00 \\
\hline
\end{tabular}

Sumber: Data Primer Diolah 2019 
Menurut hukum Engel, ketika terjadi penurunan pendapatan, porsi yang dibelanjakan untuk pangan semakin meningkat. Sebaliknya jika pendapatan meningkat maka konsumen akan membelanjakan pendapatannya untuk pangan dengan porsi yang semakin mengecil.

\section{Tingkat Konsumsi Energi dan Protein Rumah Tangga Petani}

Tingkat konsumsi untuk pangan pokok pada keluarga petani di Desa Cendi Menik untuk pangan pokok menempati urutan tertinggi kedua setelah minyak kelapa, yakni sebesar 307,64 Kkalori/kapita/hari; sedangkan minyak kelapa sebesar 327,65 Kkalori/kapita/hari. Hal ini dikarenakan menu lauk umumnya digoreng dan minyak goreng diproduksi sendiri. Kecamatan Sekotong, termasuk Desa Cendi Menik juga sebagai sentra kelapa. Rincian tentang jumlah konsumsi kalori anggota rumahtangga petani di Desa Cendi Menik tahun 2019 pada Tabel 5.

Tabel 5. Jumlah Konsumsi Kalori Rumah Tangga Petani Sawah Irigasi di Desa Cendi Manik Kecamatan Sekotong Tahun 2019

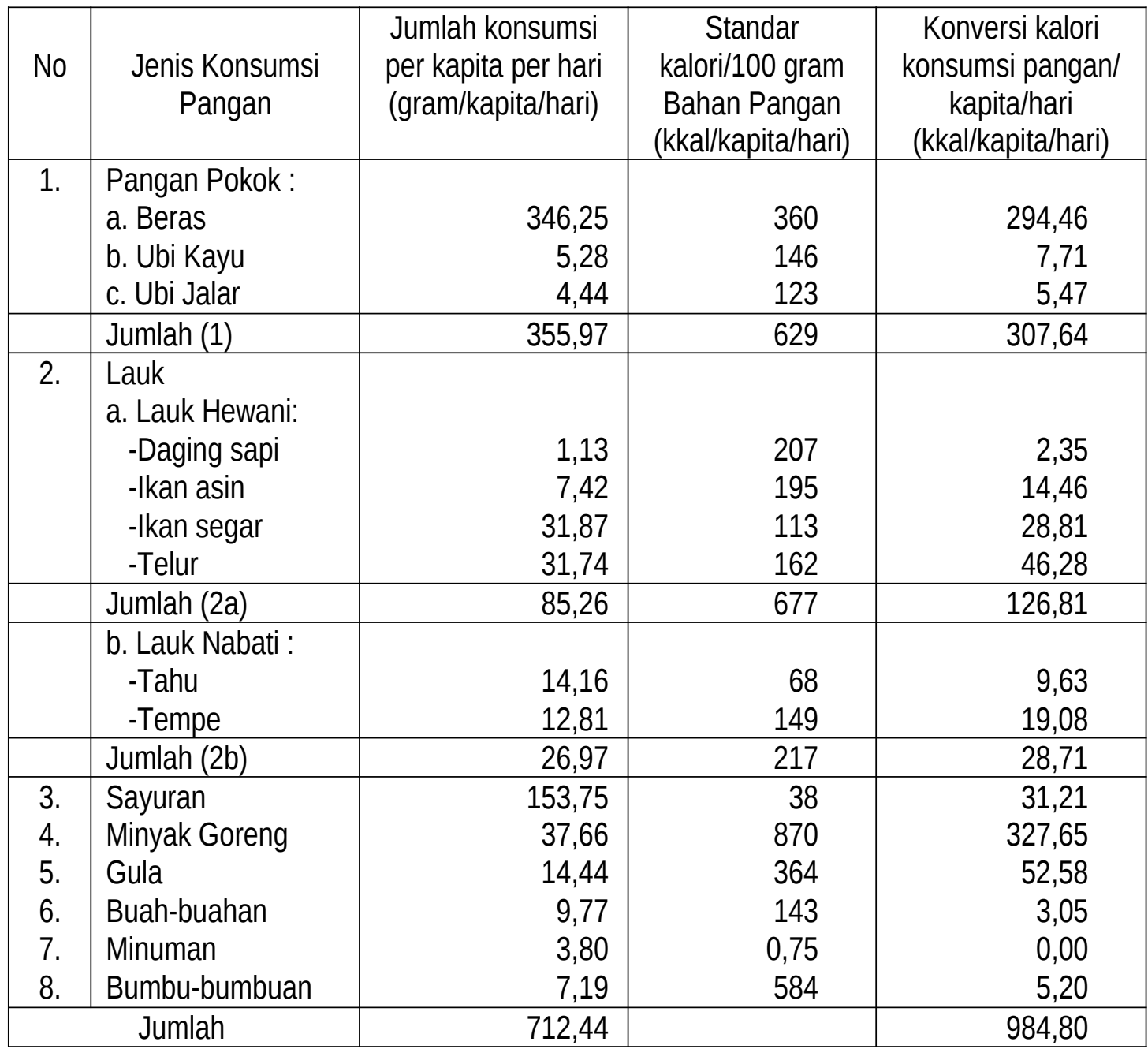

Distribusi rumah tangga petani sawah irigasi di Desa Cendi Manik Kecamatan Sekotong rata-rata berada di bawah standar nilai minimal energi yang diperlukan oleh setiap orang dalam satu hari, rincian selengkapnya pada Tabel 6. 
Tabel 6. Distribusi Kecukupan Energi Rumah Tangga Petani Sawah Irigasi di Desa Cendi Manik Kecamatan Sekotong Tahun 2019

\begin{tabular}{|c|l|r|r|}
\hline No. & \multicolumn{1}{|c|}{ Kategori Angka Kecukupan Energi } & Jumlah (orang) & $\begin{array}{c}\text { Persentase } \\
(\%)\end{array}$ \\
\hline 1. & Tahan Pangan & 3 & 15 \\
2. & Tidak Tahan Pangan & 17 & 85 \\
\hline \multicolumn{2}{|c|}{ Total } & 20 & 100 \\
\hline
\end{tabular}

Sumber: Data Primer Diolah 2019

Lebih lanjut hasil penelitian terdapat $85 \%$ rumah tangga petani yang serapan energinya berada dibawah standar minimal kecukupan energi, sedangkan sisanya yakni $15 \%$ telah mampu memenuhi kecukupan energi yang dibutuhkan tubuh untuk hidup sehat.

Berdasarkan proporsi pengeluaran pangan terhadap total pengeluaran dan tingkat konsumsi energi dapat dilakukan klasifikasi ketahanan pangan. Rincian selengkapnya tentang klasifikasi tingkat ketahanan pangan rumahtangga petani di Desa Cendi Menik tahun 2019 pada Tabel 7.

Tabel 7. Klasifikasi Ketahanan Pangan RumahTangga Petani Sawah Irigasi di Desa Cendi Manik Kecamatan Sekotong Tahun 2019

\begin{tabular}{|l|r|r|}
\hline \multicolumn{1}{|c|}{ Kelasifikasi Ketahanan Pangan } & $\begin{array}{c}\text { Rumah tangga } \\
\text { (Orang) }\end{array}$ & $\begin{array}{c}\text { Persentase } \\
(\%)\end{array}$ \\
\hline 1. Rawan Pangan (PPP $>60 \%$ TKE $<80 \%$ AKG) & 15 & 75 \\
2. Kurang Pangan (PPP $<60 \%$ TKE $<80 \%$ AKG) & 2 & 10 \\
3. Rentan Pangan (PPP $>60 \%$ TKE $>80 \%$ AKG) & 3 & 15 \\
4. Tahan Pangan (PPP $<60 \%$ TKE $>80 \%$ AKG) & 0 & 0 \\
\hline Jumlah & 20 & 100 \\
\hline
\end{tabular}

Sumber: Data Primer Diolah 2019

Tabel 7 merinci bahwa klasifikasi ketahanan pangan rumah tangga petani sawah irigasi di Desa Cendi Manik secara berurutan dari yang paling banyak hingga yang paling sedikit ialah rawan pangan sebanyak 15 responden atau 75\%, rentan pangan sebanyak 3 responden atau 15\%, kurang pangan sebanyak 2 responden atau 10\%, dan tidak ada responden yang tergolong tahan pangan, sehingga dapat disimpulkan bahwa rumah tangga petani sawah irigasi di Desa Cendi Manik Kecamatan Sekotong terbilang rawan pangan. Walaupun petani sawah irigasi di Desa Cendi Manik dapat memproduksi beras sendiri dan lebih memilih menyimpanya namun tidak menjamin terpenuhinya kebutuhan pangan dan penyerapan energi. Hal ini dikarenakan pemenuhan kebutuhan energi tidak hanya diperoleh dari bahan pokok makanan (beras) tapi juga dari bahan makanan lain.

\section{Ketersediaan Pangan Pokok (Beras) Rumah Tangga Petani}


Ketersediaan pangan rumah tangga petani ditentukan oleh jumlah input dan output pangan dalam jangka waktu tertentu. Rincian tentang tingkat ketersediaan pangan pokok (beras) pada rumahtangga petani di lokasi penelitian selengkapnya pada Tabel 8.

Tabel 8. Tingkat Ketersediaan Pangan Pokok (beras) pada Rumah Tangga Petani Sawah Irigasi di Desa Cendi Manik Kecamatan Sekotong Tahun 2019

\begin{tabular}{|l|r|r|r|r|}
\hline \multirow{2}{*}{ Keterangan } & \multicolumn{2}{|c|}{ Jumlah Beras $(\mathrm{kg})$} & \multicolumn{2}{c|}{ Jumlah Energi } \\
\cline { 2 - 5 } & Per bulan & $\begin{array}{c}\text { Per kapita/ } \\
\text { hari }\end{array}$ & $\begin{array}{c}\text { Kkal/kapita/ } \\
\text { hari }\end{array}$ & $\begin{array}{c}\text { Persen- } \\
\text { tase (\%) }\end{array}$ \\
\hline Input & 328,38 & 3,56 & $12.806,25$ & 100 \\
$\begin{array}{l}\text { 1. Produksi usahatani } \\
\text { 2. Pembelian }\end{array}$ & 0 & 0 & 0 & 0 \\
3. Raskin & 0 & 0 & 0 & 0 \\
\hline \multicolumn{1}{|c}{ Jumlah } & 328,38 & 3,56 & $12.806,25$ & 100 \\
\hline Output & 0 & & 0 & 0 \\
1. Penjualan & 0,77 & 0,007 & 28,50 & 100 \\
2. Zakat Fitrah & 0 & 0 & 0 & 0 \\
3. Diberikan pada pihak lain & 0,77 & 0,007 & 28,50 & 100 \\
\hline \multicolumn{1}{c}{ Jumlah } & $\mathbf{3 2 7 . 6 1}$ & $\mathbf{3 , 5 5 3}$ & $\mathbf{1 2 . 7 7 7 , 7 5}$ & $\mathbf{1 0 0}$ \\
\hline \multicolumn{1}{|c|}{ Ketersediaan } & & &
\end{tabular}

Sumber: Data Primer Diolah 2019

Berdasarkan Tabel 8 dapat dilihat bahwa sumber input pangan pokok (beras) petani sawah irigasi hanya bersumber dari produksi sendiri atau dari hasil kegaiatan pertanian sendiri sebanyak 328,38 kg/bulan atau 3,56 kg/kapita/hari dengan menghasilkan energi sebesar $12.806,25 \mathrm{kkal} / \mathrm{kapita} / \mathrm{hari}$ atau $100 \%$ dari sumber penerimaan pangan. Sumber pembelian bernilai nol, disebabkan petani lebih memilih menyimpan hasil usahatani (beras) daripada menjualnya sehingga tidak ada pembelian selama stok beras masih tersedia. Sumber pangan pokok dari raskin juga bernilai nol disebabkan sejak tahun 2018 pemerintah sudah tidak menyalurkan beras miskin (raskin) kepada masyarakat lagi. Output pangan pokok petani sawah irigasi dengan memberikan zakat fitrah sebesar $0,77 \mathrm{~kg} / \mathrm{bulan}$ atau 0,007 kg/kap/hari yang menghasilkan energi sebesar $28,50 \mathrm{kkal} / \mathrm{kap} / \mathrm{hari}$ atau $100 \%$ dari total output. Adapun untuk output penjualan dan diberikan pihak lain tidak dilakukan atau bernilai nol.

\section{Akses Pangan RumahTangga Petani}

Akses pangan rumah tangga petani dapat dinilai berdasarkan tiga aspek yakni aspek fisik, ekonomi, dan sosial. Rincian tentang akses pangan tersebut pada Tabel 9.

Berdasarkan Tabel 9 diketahui bahwa akses pangan rumah tangga dapat dinilai berdasarkan tiga aspek yakni aspek fisik, ekonomi, dan sosial.Diperoleh indeks komposit gabungan dengan menjumlahkan nilai (skoring) dari masing-masing aspek.Jumlah keseluruhan skor dari ketiga aspek adalah 42 kemudian dibagi dengan jumlah skor yang diperoleh dari ketiga aspek yakni 25 sehingga diperoleh skor akhir yaitu 1,68 atau dibulatkan menjadi 2 yang artinya akses pangan di Desa Cendi Manik Kecamatan Sekotong terbilang rendah. 
Tabel 9. Akses Pangan Rumah Tangga Petani Sawah Irigasi di Desa Cendi Manik Kecamatan Sekotong Tahun 2019

\begin{tabular}{|c|l|l|c|}
\hline No & $\begin{array}{l}\text { Aspek Akses } \\
\text { Pangan }\end{array}$ & \multicolumn{1}{c|}{ Indikator } & Skor \\
\hline 1 & Aspek Fisik & $\begin{array}{l}\text { a. Rasio Konsumsi Normatif per kapita terhadap } \\
\text { Ketersediaan Pangan Pokok } \\
\text { b. Persentase jalan yang tidak dapat dilaui } \\
\text { kendaraan roda empat } \\
\text { c. Persentasekecamatan yang tidak memiliki } \\
\text { pasar dan jarak terdekat kepasar }>3 \text { km }\end{array}$ & 6 \\
\hline 2 & Aspek Ekonomi & $\begin{array}{l}\text { a. Persentase petani hidup di bawah garis } \\
\text { kemiskinan } \\
\text { b. Persentase petani yang bekerja <36 jam per } \\
\text { pekan } \\
\text { c. Pendapatan RT petani per kapita/tahun }\end{array}$ & 1 \\
\hline 3 & Aspek Sosial & a. Persentase pendidikan petani tidak tamat SD & 6 \\
\hline \multicolumn{1}{|c|}{ Jumlah } & 6 \\
\hline
\end{tabular}

Sumber: Data Primer Diolah 2019

\section{Konsumsi Pangan Rumah Tangga Petani}

Pada Tabel 10 menjelaskan bahwa rata-rata konsumsi energi rumah tangga adalah 3.393,39 kkal yang menunjukkan bahwa rata-rata konsumsi energi setiap anggota rumah tangga ialah 848,35 kkal/kapita/hari yang artinya masih berada di bawah AKG yang dianjurkan yaitu $2.150 \mathrm{kkal} / \mathrm{kapita} / \mathrm{hari}$.

Tabel 10. Konsumsi energi dan protein serta tingkat konsumsi gizi (TKG) Rumah Tangga Petani Sawah Irigasi di Desa Cendi Manik Kecamatan Sekotong Tahun 2019

\begin{tabular}{|l|r|r|r|r|}
\hline \multirow{2}{*}{ Keterangan } & \multicolumn{2}{|c|}{ Energi (kkal) } & \multicolumn{2}{c|}{ Protein (gram) } \\
\cline { 2 - 5 } & Rumah Tangga & $\begin{array}{c}\text { Per kapita } \\
\text { per hari }\end{array}$ & Rumah Tangga & $\begin{array}{l}\text { Per kapita } \\
\text { per hari }\end{array}$ \\
\hline Konsumsi & $3.393,39$ & 848,35 & 188,88 & 47,22 \\
AKG yang dianjurkan & 8.600 & $2.150,00$ & 228,00 & 57,00 \\
TKG (\%) & 39,46 & 39,46 & 82,84 & 82,84 \\
\hline
\end{tabular}

Sumber: Data Primer Diolah 2019 
Tingkat Kecukupan Gizi untuk energi (TKE) sebesar 39,46\% yag termasuk dalam kategori defisit. Hal ini disebabkan karena responden dalam memenuhi kebutuhan energinya hanya mengkonsumsi nasi sebagai makanan pokok, sedangkan komoditas lainya seperti umbiumbian hanya sebagai pelengkap atau hanya mengkonsumsi jika ingin mengkonsumsinya.

Rata-rata konsumsi protein rumah tangga sebesar 47,2 gram/kapita/hari, menunjukkan bahwa rata-rata konsumsi protein setiap anggota rumah tangga berada dibawah AKG yang dianjurkan yaitu 57 gram/kapita/hari. Tingkat Kecukupan Gizi untuk protein (TKP) sebesar $82,84 \%$ sehingga berada pada kategori sedang. Hal ini disebabkan, sebagian besar responden memenuhi kebutuhan protein dengan mengkonsumsi tahu dan tempe serta telur sedangkan makanan lain yang mengandung protein tinggi seperti Almond, dada ayam, susu, brokoli, dan tuna jarang dikonsumsi.

\section{Masalah yang dihadapi Rumah Tangga Petani}

Masalah yang dirasakan oleh rumah tangga dalam mewujudkan ketahanan pangan rumah tangga yakni dari segi teknis/lingkungan fisik. Secara berurutan, masalah yang paling banyak dirasakan oleh responden adalah masalah ketersediaan air sebanyak 9 responden (45\%), kesuburan tanah sebanyak 8 responden (40\%), dan hama penyakit sebanyak 3 responden (15\%).

\section{KESIMPULAN DAN SARAN}

\section{Kesimpulan}

1. Jumlah pendapatan petani sawah irigasi sebesar Rp $17.734 .644,11 /$ tahun, terdiri dari pendapatan dari pertanian sebesar Rp 7.837.944,11/tahun dan pendapatan dari luar pertanian sebesar Rp 9.896.700/tahun. Rata-rata pengeluaran rumah tangga petani sebesar Rp 1.184.001/bulan atau Rp 14.208.012/tahun, terdiri dari pengeluaran untuk pangan sebesar Rp 795.013/bulan atau Rp 9.540.156/tahun dan pengeluaran untuk non pangan sebesar Rp 388.988/bulan atau Rp 4.667.856/tahun.

2. Kondisi ketahanan pangan rumah tangga petani sawah irigasi tergolong rawan pangan sebanyak 15 responden (75\%), kurang pangan sebanyak 2 responden (10\%), rentan pangan sebanyak 3 responden (15\%), dan tidak ada responden yang tergolong tahan pangan.

3. Masalah yang dirasakan oleh petani sawah irigasi dalam mewujudkan ketahanan pangan rumah tangga pada aspek teknis/ lingkungan fisik saja. Secara berurutan masalah yang paling dirasakan petani ialah ketersediaan air sebanyak 9 responden (45\%), kesuburan tanah (40\%), dan hama penyakit sebanyak 3 orang (15\%).

\section{Saran}

1. Disarankan kepada rumah tangga petani agar lebih banyak mengkonsumsi makanan sehat yang mengandung kalori dan protein tinggi untuk memenuhi standar kebutuhan energi dan protein per kapita; seperti buah alpukat, pepaya, telur, ikan, dan lain-lain. 
2. Kepada pemerintah disarankan agar melakukan sosialisasi terkait pentingnya pemenuhan gizi dan jenis makanan bergizi kepada rumah tangga petani sawah irigasi, sehingga menambah wawasan dan kesadaran petani.

3. Untuk mengatasi masalah ketersediaan air yang masih terbatas dapat dilakukan dengan pengawasan pemanfaatan embung oleh pemerintah dan membantu petani yang tidak mampu menjangkau embung dengan melakukan penggalian sumur bor.

\section{DAFTAR PUSTAKA}

Adiguno, R.; Sihombing, Luhut, Hutajulu, A.T. 2013. Analisis Akses Pangan di Provinsi Sumatera Utara. Program Studi Agribisnis. Fakultas Pertanian. Universitas Sumatera Utara. Medan.

Azizah,S; Putritamara, Jaisy Aghniarahim; Febrianto, Nanang. 2019. Aspek Kehidupan Petani Gurem. Malang: UB Press.

Badan Ketahanan Pangan Kementerian Pertanian. 2018. Peta Ketahanan dan Kerentanan Pangan.Republik Indonesia.

Badan Pusat Statistik. 2018. Kecamatan Sekotong Dalam Angka 2018. Badan Pusat Statistik. Lombok Barat.

Basyuni, H.W. 2018. Studi Ketahanan Pangan Rumah Tangga Petani Konservasi Lahan Kering di Kecamatan Jerowaru Kabupaten Lombok Timur. [Skripsi, Unpublished]. Mataram: Universitas Mataram.

Damayanti, VL; Khairudin; dan Fikri. 2016. Analisis Faktor-Faktor yang Mempengaruhi Ketahanan Pangan Rumah Tangga Petani (Studi Kasus: Desa Timbulharjo, Sewon, Bantul).Ekonomi dan Studi Pembangunan 17: 90-96.

Hanani AR, N. 2008. Ketersediaan dan Kemandirian Pangan.Dalam: Seminar Nasional Pembangunan Nasional. Universitas Brawijaya 12 November 2016. Halaman 88-89.

Hardiansyah, et al., 2013. Kecukupan Energi, Protein, Lemak, dan Karbohidrat. Departemen Gizi FK UI. 
Lampiran 1. Nilai Skoring Komposit Akses Pangan

\begin{tabular}{|c|c|c|c|}
\hline Standar & Indikator & Ranges & Kondisi Akses Pangan \\
\hline \multirow{3}{*}{ Aspek Fisik } & $\begin{array}{l}\text { a. Rasio konsumsi normatif } \\
\text { per kapita terhadap } \\
\text { ketersediaan pangan } \\
\text { pokok dan umbi-umbian }\end{array}$ & $\begin{array}{l}\text { 1. }>=1,5 \\
\text { 2. } 1,25-<1,5 \\
\text { 3. } 1,0-<1,25 \\
\text { 4. } 0,75-<1,0 \\
\text { 5. } 0,5-<0,75 \\
6 .<0,5\end{array}$ & $\begin{array}{l}\text { Sangat rendah } \\
\text { Rendah } \\
\text { Cukup rendah } \\
\text { Cukup tinggi } \\
\text { Tinggi } \\
\text { Sangat Tinggi }\end{array}$ \\
\hline & $\begin{array}{l}\text { p. Persentase jalan yang tidak } \\
\text { dapat dilaui kendaraan } \\
\text { roda empat }\end{array}$ & $\begin{array}{l}\text { 1. }>=30 \% \\
\text { 2. } 25 \%-<30 \% \\
\text { 3. } 20 \%-<25 \% \\
\text { 4. } 15 \%-<20 \% \\
\text { 5. } 10 \%-<15 \% \\
\text { 6. }<10 \%\end{array}$ & $\begin{array}{l}\text { Sangat rendah } \\
\text { Rendah } \\
\text { Cukup rendah } \\
\text { Cukup tinggi } \\
\text { Tinggi } \\
\text { Sangat Tinggi }\end{array}$ \\
\hline & $\begin{array}{l}\text { c. Persentase kecamatan } \\
\text { yang tidak memiliki pasar } \\
\text { dan jarak terdekat ke pasar } \\
>3 \mathrm{~km}\end{array}$ & $\begin{array}{l}\text { 1. }>=62,5 \% \\
\text { 2. } 50 \%-<62 \% \\
\text { 3. } 37,5 \%-<50 \% \\
\text { 4. } 25 \%-<37,5 \% \\
\text { 5. } 12,5 \%-<25 \% \\
\text { 6. }<12,5 \%\end{array}$ & $\begin{array}{l}\text { Sangat rendah } \\
\text { Rendah } \\
\text { Cukup rendah } \\
\text { Cukup tinggi } \\
\text { Tinggi } \\
\text { Sangat Tinggi }\end{array}$ \\
\hline \multirow{3}{*}{$\begin{array}{l}\text { Aspek } \\
\text { Ekonomi }\end{array}$} & $\begin{array}{l}\text { a. Persentase petani hidup } \\
\text { dibawah garis kemiskinan }\end{array}$ & $\begin{array}{l}\text { 1. }>=35 \% \\
\text { 2. } 25 \%-<35 \% \\
\text { 3. } 20 \%-<25 \% \\
\text { 4. } 15 \%-<20 \% \\
\text { 5. } 10 \%-<15 \% \\
6 .<10 \%\end{array}$ & $\begin{array}{l}\text { Sangat rendah } \\
\text { Rendah } \\
\text { Cukup rendah } \\
\text { Cukup tinggi } \\
\text { Tinggi } \\
\text { Sangat Tinggi }\end{array}$ \\
\hline & $\begin{array}{l}\text { p. Persentasse petani yang } \\
\text { bekerja <36 jam per } \\
\text { pekan }\end{array}$ & $\begin{array}{l}\text { 1. }>=50 \% \\
\text { 2. } 40 \%-<50 \% \\
\text { 3. } 30 \%-<40 \% \\
\text { 4. } 20 \%-<30 \% \\
\text { 5. } 10 \%-<20 \% \\
\text { 6. }<10 \%\end{array}$ & $\begin{array}{l}\text { Sangat rendah } \\
\text { Rendah } \\
\text { Cukup rendah } \\
\text { Cukup tinggi } \\
\text { Tinggi } \\
\text { Sangat Tinggi } \\
\end{array}$ \\
\hline & $\begin{array}{l}\text { c. Pendapatan RT petani per } \\
\text { kapita/tahun }\end{array}$ & $\begin{array}{l}\text { 1. }<365 \$ \\
\text { 2. } 365 \$-<730 \$ \\
\text { 3. } 730 \$-<1095 \$ \\
\text { 4.1095\$-<1460\$ } \\
\text { 5. } 1460 \$-<2190 \$ \\
\text { 6. }>=2190 \$\end{array}$ & $\begin{array}{l}\text { Sangat rendah } \\
\text { Rendah } \\
\text { Cukup rendah } \\
\text { Cukup tinggi } \\
\text { Tinggi } \\
\text { Sangat Tinggi }\end{array}$ \\
\hline Aspek Sosial & $\begin{array}{l}\text { a. Persentase pendidikan } \\
\text { petani tidak tamat SD }\end{array}$ & $\begin{array}{l}\text { 1. }>=50 \% \\
\text { 2. } 40 \%-<50 \% \\
\text { 3. } 30 \%-<40 \% \\
\text { 4. } 20 \%-<20 \%\end{array}$ & $\begin{array}{l}\text { Sangat rendah } \\
\text { Rendah } \\
\text { Cukup rendah } \\
\text { Cukup tinggi }\end{array}$ \\
\hline
\end{tabular}




\begin{tabular}{|l|l|l|l|}
\hline & & $5.10 \%-<20 \%$ & Tinggi \\
& & $6 .<10 \%$ & Sangat Tinggi \\
\hline
\end{tabular}

Sumber: Badan Ketahanan Pangan, 2011 